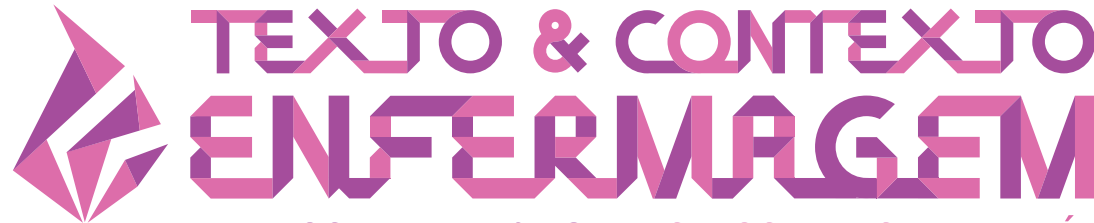

TEXT \& CONTEXT NURSING TEXTO \& CONTEXTO ENFERMERÍA

\section{RESILIENCE AND SELF-CARE IN PEOPLE WITH DIABETES MELLITUS}

\author{
Julia Estela Willrich Boell' \\ Denise Maria Guerreiro Vieira da Silva ${ }^{1}$ \\ Maria Elena Echevarria Guanilo' ${ }^{1}$ \\ Kathleen Hegadoren ${ }^{2}$ (i) \\ Betina Hörner Schlindwein Meirelles ${ }^{1}$ \\ Samara Rabelo Suplici ${ }^{1}$ (c)
}

${ }^{1}$ Universidade Federal de Santa Catarina, Programa de Pós-Graduação em Enfermagem. Florianópolis, Santa Catarina, Brasil. ${ }^{2}$ University of Alberta, Faculty of Nursing. Edmonton, Alberta, Canada.

\begin{abstract}
Objective: to investigate the association between resilience and self-care in people with diabetes mellitus treated in Primary Health Care.

Method: Cross-sectional study, sample consisting of 362 people, aged 18 years or older, diagnosed with diabetes for at least one year. Descriptive analyzes and comparison of means were performed, assuming statistical significance with a value of $p<0.05$. The Resilience Scale and Questionnaire on Diabetes Self-Care Activities were applied, containing six dimensions: general food, specific food, physical activity, blood glucose monitoring, foot care, medication use, plus three items on smoking. Data collection took place between December and May 2016, in ten Health Centers in a city in the south of the country.

Results: among the 15 self-care activities, four showed a statistically significant association when compared to the average resilience, highlighting: healthy eating and professional guidance, desirable sweet consumption, blood sugar assessment as recommended.

Conclusion: the results obtained highlight the relationship between high averages of resilience and adequate performance in the care of diabetes mellitus.
\end{abstract}

DESCRIPTORS: Nursing. Diabetes mellitus. Psychological resilience. Self-care. Primary health care. 


\section{RESILIÊNCIA E AUTOCUIDADO EM PESSOAS COM DIABETES MELLITUS}

\section{RESUMO}

Objetivo: investigar a associação entre resiliência e autocuidado em pessoas com diabetes mellitus atendidas na Atenção Primária à Saúde.

Método: Estudo transversal, amostra composta por 362 pessoas, com idade igual ou superior a 18 anos, com diagnóstico de diabetes há pelo menos um ano. Foram realizadas análises descritivas e de comparação de médias, assumindo significância estatística com valor de $p<0,05$. Aplicou-se Escala de Resiliência e Questionário de Atividades de Autocuidado com Diabetes, contendo seis dimensões: alimentação geral, alimentação específica, atividade física, monitorização da glicemia, cuidados com pés, uso de medicamento, acrescidos de três itens sobre tabagismo. A coleta de dados ocorreu entre dezembro a maio de 2016, em dez Centros de Saúde de uma capital do sul do país.

Resultados: das 15 atividades de autocuidado, quatro apresentaram associação estatisticamente significativa quando comparadas à média de resiliência, destacando-se: alimentação saudável e orientação profissional, consumo de doces desejável, avaliação do açúcar no sangue conforme recomendado.

Conclusão: os resultados obtidos apontam a relação entre médias altas de resiliência e o desempenho adequado nos cuidados do diabetes mellitus.

DESCRITORES: Enfermagem. Diabetes mellitus. Resiliência psicológica. Autocuidado. Atenção primária à saúde.

\section{ARTÍCULO ORIGINAL RESILIENCIA Y AUTOCUIDADO EN PERSONAS CON DIABETES MELLITUS}

\section{RESUMEN}

Objetivo: investigar la asociación entre resiliencia y autocuidado en personas con diabetes mellitus tratadas en Atención Primaria de Salud.

Método: estudio transversal, muestra compuesta por 362 personas, mayores de 18 años, diagnosticadas con diabetes durante al menos un año. Se realizaron análisis descriptivos y comparación de promedios, asumiendo significación estadística con un valor de $p<0,05$. Se aplicó la Escala de Resiliencia y el Cuestionario sobre las actividades de autocuidado de la diabetes, que contiene seis dimensiones: alimentación general, alimentación específica, actividad física, monitoreo de glucosa en sangre, cuidado de los pies, uso de medicamentos, más tres artículos sobre fumar. La recopilación de datos tuvo lugar entre diciembre y mayo de 2016, en diez centros de salud en una capital en el sur del país.

Resultados: de las 15 actividades de autocuidado, cuatro han mostrado una asociación estadísticamente significativa en comparación con el promedio de resiliencia, destacando:alimentación saludable y orientación profesional, consumo de dulces, evaluación de azúcar en la sangre según lo recomendado.

Conclusión: los resultados obtenidos apuntan a la relación entre altos promedios de resiliencia y desempeño adecuado en el cuidado de la diabetes mellitus.

DESCRIPTORES: Enfermería. Diabetes mellitus. Resiliencia psicológica. Autocuidado. Atención primaria de salud. 


\section{INTRODUCTION}

According to data from the International Diabetes Federation, ${ }^{1}$ the prevalence of diabetes mellitus affects approximately $8.8 \%$ of the world population. In Central and South American countries, it is estimated that 26 million people have this disease, with Brazil ranked fourth in the ranking of the 10 countries with the highest number of people with DM: approximately 12.5 million Brazilians live with the disease, with 5.7 million unaware of their diagnosis. ${ }^{1}$ According to data from the Surveillance of Risk and Protection Factors for Chronic Diseases by Survey By telephone in 2013, there was a $6.9 \%$ prevalence of DM in men and women in the population. ${ }^{2}$ In addition to this expansion of the disease, its severity and complexity for the person and their family and the impact it has on the Brazilian health system must be considered, as the changes that this can bring to the lives of people tend to compromise their quality of life.

Thus, it is necessary to develop health education in relation to self-care for people with DM. This can be defined as a set of practices and activities that the person performs for their own benefit in maintaining life, health and well-being. It is about ceasing to be passive in relation to the care and guidelines proposed by health professionals. ${ }^{3}$ Studies have shown that people with DM have better adherence to drug treatment and have greater difficulty in adhering to diet and exercise. ${ }^{4-5}$

Health professionals, particularly nurses, aim to promote the health of people with DM, so that they can have better control over the disease. Promoting the person's adherence to care and treatments is of great relevance for the adequate management of DM. This can be achieved by encouraging lifestyle changes that promote adjustments for living with chronicity. The guidelines on self-care received by the person with $\mathrm{DM}$, the fact of adopting healthy lifestyle habits and the skills to perform them imply prevention and reduction of complications caused by DM. ${ }^{6}$

Resilience is a construct that can contribute to disease management by people with DM, it is considered as the ability to overcome adverse situations, leaving them strengthened or transformed. ${ }^{7}$ Regarding chronic health conditions, resilience appears as a way to adapt to the disease in a more successful manner, accepting the limitations imposed by the condition, with due adherence to treatment, seeking to adapt to the situation and live positively. ${ }^{8}$

Studies on resilience have been increasing worldwide in the area of health and nursing, initially with traumatic situations and more recently with studies that indicate relevance in the treatment of chronic health conditions such as DM. ${ }^{9-11}$

The possible relationship between resilience and the self-care of people with DM is questioned in this study, with the hypothesis that those who have better resilience may have better adherence to the proposed treatment. The possibility of using this construct in search of practices that reinforce health care is questioned, contributing to people with DM having better quality of life.

Aiming to respond to the proposal, it was decided to study the relationship between the resilience of people with DM and self-care. Therefore, the objective is: to investigate the association between resilience and self-care in people with diabetes mellitus treated in Primary Health Care.

\section{METHOD}

A cross-sectional observational study conducted with people with DM treated in Primary Health Care (PHC) in the city of Florianópolis/SC, from December 2015 to May 2016.

A population of 6,251 people was obtained from the number of visits to people with DM at the 49 Health Centers (HCs) in Florianópolis, according to the record of one year of attendance by professionals in the period from 01/09/2014 to 08/30/2015, provided by the Planning Department of the Municipality of Florianópolis. In order to define the sample, a sample calculation was performed 
using the Sestatnet ${ }^{\circledR}$ website, ${ }^{12}$ with a $95 \%$ confidence interval, which indicated the minimum sample of 362 people. The choice of HCs was intentional by selecting the two Centers in each Health District that had the highest number of visits to people with DM.

The inclusion criteria for the sample were: people diagnosed with DM for more than a year, registered and treated at a $\mathrm{HC}$ in Florianópolis/SC; men and women over the age of 18. People who did not reach the minimum score on the Mini-Mental State Exam cognitive assessment test were excluded from the study, considering the cut-off point as 23 points for people with schooling and 19 points for those without schooling. The application of the Mini-Mental State Exam was justified by the need for the participant to present an adequate cognitive level to answer the applied questionnaires.

Data collection was performed by the main researcher of the study and seven collectors who were previously trained in the application of standardized sociodemographic questionnaires (age, sex, marital status, education, religion, occupation and family income) and health conditions (time of diagnosis of the disease, presence of arterial hypertension, use of medications, presence of complications of the underlying disease), as well as Self-Care Adherence and Resilience scale. For the family income variable, the value of the minimum wage was $R \$ 880.00$, this variable was answered by 354 participants. The care during the collection was followed according to previous training, performing the interview in a private environment, reading aloud the items of the scales, which the participant received in a laminated copy to accompany the reading, being completed by the collector.

Upon first contact in the waiting room or in $\mathrm{HC}$ groups, people with DM were invited to participate in the study, they were clarified regarding the objectives and benefits, allowing the person to express their willingness to participate. The interview was carried out after approval or scheduled according to the participant's preference in relation to the location and time of the interview: at home or at the CS facilities.

Resilience was assessed using the Resilience Scale developed by Connor and Davidson (CDRISC). ${ }^{13}$ Previous contact was made with the authors, who developed the validated version available to the Brazilian population, designated as: Connor-Davidson Resilience Scale for Brazil (RISC-Br). ${ }^{14} \mathrm{The}$ instrument consists of 25 items, evaluated using a likert scale, with the following answer options: not at all true (zero); rarely true (one); sometimes true (two); often true (three), almost always true (four). Total scores can range from zero to 100 points, values close to 100 indicate better resilience. The scale was evaluated in relation to internal consistency, test/retest, convergent validity and discriminant validity and the structural factor, and has a satisfactory psychometric property, which distinguishes between people with greater and lesser resilience.

Self-care was assessed using the Questionnaire on Diabetes Self-Care Activities (QAD). The Brazilian version ${ }^{15}$ originated from the Summary of Diabetes Self-Care Activities Questionnaire (SDSCA $),{ }^{16}$ which was translated and cross-culturally adapted and had similar psychometric properties as the original instrument, ensuring validity and reliability to assess treatment adherence through the self-care levels in people with DM. The questionnaire has six dimensions: general diet (two items), specific diet (three items), physical activity (two items), blood glucose monitoring (two items), foot care (three items) and medication (three items), in addition to three items on smoking. The score of the answers ranges from zero to seven and corresponds to the behaviors related to the last seven days, where zero indicates the least desirable situation and seven the most desirable. In addition to these questions, the instrument has three items in relation to smoking. Higher scores indicate better performance of self-care activities. ${ }^{15}$ 
For this study, in relation to adherence to self-care practices, it was considered: desirable self-care behavior ( 7 days); moderate self-care behavior ( 6 to 5 days); and low self-care behavior ( 0 to 4 days). The specific diet domain presents the items: eating meat and sweets, with inverse values; thus, the categorization was also inverse for these items and changed as to the days of follow-up, considering thus: desirable self-care behavior ( 0 days); moderate self-care behavior ( 1 to 2 days); and low self-care behavior ( 3 to 7 days). For the physical activity domain, it was considered: desirable self-care behavior ( 7 to 4 days); moderate self-care behavior ( 3 to 2 days); and low self-care behavior (0 to 1 day).

Data analysis was performed in the Statistical Package for Social Science SPSS $®$ version 20.0.17, descriptive, dispersion and central tendency analyzes of variables were performed, and the mean, standard deviation, maximum and minimum values were calculated. One-way ANOVA was used to compare more than two averages. Statistical significance was determined with a $p$ value of $<0.05$.

All ethical principles determined by Resolution 466/12 of the National Health Council were respected by complying with the requirements of the Free and Informed Consent Form. The study was approved by the Municipal Administration.

\section{RESULTS}

The average age of the study participants was 62.4 (SD 11.5). The female gender prevailed $(64 \%)$ and the majority declared being married (55.5\%). Few participants never studied (6.6\%), most had completed elementary school (56\%), and at the time of the interview, most declared being retired or being a pensioner $(62 \%)$, with a predominance of income between one to three minimum wages $(37 \%)$. Arterial hypertension was declared by the majority $(68 \%)$ and complications of the disease appeared in less than half of the participants $(21 \%)$.

The aspects of care that showed a statistically significant difference $(p<0.05)$ were: following a healthy diet, following dietary guidelines, reduced intake of sweets and taking insulin injections as recommended. In these aspects, the average resilience score was higher in people with desirable self-care behaviors (Table 1).

The results obtained in the PAF items in relation to smoking were expressed in Table 2. Regarding smoking, most participants declared that they had never smoked.

Table 1 - Distribution and differences in mean resilience according

to self-care reported by people with diabetes mellitus.

Florianópolis, SC, Brazil, 2015 to 2016. $(n=362)$.

\begin{tabular}{lrcc}
\hline Variable & $\mathbf{n}(\%)$ & Mean resilience (SD) & $\boldsymbol{P}$ \\
\hline General Diet & & & \\
Follow a healthy diet & & & \\
$\quad$ Desirable & $157(43.4)$ & $82.4(13.1)$ & $0.015^{*}$ \\
Moderate & $67(18.5)$ & $81.6(14.8)$ & \\
Low & $138(38.1)$ & $77.8(14.3)$ & \\
Follow diet guidelines & & & \\
Desirable & $103(28.5)$ & $82.4(13.3)$ & \\
Moderate & $54(14.9)$ & $83.0(13.5)$ & \\
Low & $205(56.6)$ & $78.8(14.3)$ & \\
\hline
\end{tabular}


Table 1 - Cont.

\begin{tabular}{|c|c|c|c|}
\hline Variable & $\mathrm{n}(\%)$ & Mean resilience (SD) & $P$ \\
\hline \multicolumn{4}{|l|}{ Specific Food } \\
\hline $\begin{array}{l}\text { Eat five or more servings of fruits and / or } \\
\text { vegetables }\end{array}$ & & & 0.056 \\
\hline Desirable & $192(53.0)$ & $81.2(13.7)$ & \\
\hline Moderate & $50(13.8)$ & $83.4(11.9)$ & \\
\hline Low & $120(33.1)$ & $78.2(15.1)$ & \\
\hline Eating red meats and / or whole milk products & & & 0.683 \\
\hline Desirable & $249(68.8)$ & $80.8(13.8)$ & \\
\hline Moderate & $59(16.3)$ & $80.3(13.5)$ & \\
\hline Low & $54(14.9)$ & $79.0(15.7)$ & \\
\hline Eating sweets & & & 0.034 * \\
\hline Desirable & $147(40.6)$ & $82.0(13.0)$ & \\
\hline Moderate & $129(35.6)$ & $81.0(13.0)$ & \\
\hline Low & $86(23.8)$ & $77.1(16.6)$ & \\
\hline \multicolumn{4}{|l|}{ Physical activity } \\
\hline $\begin{array}{l}\text { Perform physical activity - minimum } 30 \\
\text { minutes }\end{array}$ & & & 0.590 \\
\hline Desirable & $112(30.9)$ & $81.3(13.6)$ & \\
\hline Moderate & $62(17.1)$ & $81.3(12.2)$ & \\
\hline Low & $188(51.9)$ & $79.7(14.8)$ & \\
\hline Perform specific physical exercise & & & 0.145 \\
\hline Desirable & $86(23.8)$ & $82.2(13.3)$ & \\
\hline Moderate & $60(16.6)$ & $82.4(11.8)$ & \\
\hline Low & $216(59.7)$ & $79.3(14.8)$ & \\
\hline \multicolumn{4}{|l|}{ Blood glucose monitoring } \\
\hline Assess blood sugar $(n=120)$ & & & 0.633 \\
\hline Desirable & $88(73.3)$ & $78.9(14.4)$ & \\
\hline Moderate & Zero (0) & - & \\
\hline Low & $32(26.7)$ & $80.30(14.0)$ & \\
\hline $\begin{array}{l}\text { Assess blood sugar the recommended number } \\
\text { of times }(n=120)\end{array}$ & & & 0.422 \\
\hline Desirable & $75(62.5)$ & $79.9(14.3)$ & \\
\hline Moderate & $1(0.8)$ & 98.0 & \\
\hline Low & $44(36.7)$ & $79.45(14.3)$ & \\
\hline \multicolumn{4}{|l|}{ Foot care } \\
\hline Foot examination & & & 0.171 \\
\hline Desirable & $239(66.0)$ & $81.5(13.4)$ & \\
\hline Moderate & $4(1.1)$ & $81.2(11.95)$ & \\
\hline Low & 119 (32.9) & $78.5(15.1)$ & \\
\hline $\begin{array}{l}\text { Examine the inside of the shoes before putting } \\
\text { them on }\end{array}$ & & & 0.209 \\
\hline Desirable & $210(58.0)$ & $81.5(13.9)$ & \\
\hline Moderate & $6(1.7)$ & $84.0(13.0)$ & \\
\hline Low & $146(40.3)$ & $78.9(14.2)$ & \\
\hline
\end{tabular}


Table 1 - Cont.

\begin{tabular}{lrrr}
\hline Variable & $\mathbf{n}(\%)$ & Mean resilience (SD) & \multicolumn{1}{c}{$\boldsymbol{P}$} \\
\hline Dry the interdigital spaces after washing feet & & & 0.074 \\
Desirable & $303(83.7)$ & $81.2(13.8)$ & \\
Moderate & $2(0.6)$ & $85.5(3.5)$ & \\
Low & $57(15.7)$ & $76.7(14.6)$ & 0.172 \\
Medication & & & \\
Take medications as recommended (n=336) & & & \\
$\quad$ Desirable & $314(86.7)$ & $80.8(13.53)$ & $0.015^{*}$ \\
Moderate & $10(2.8)$ & $74.8(17.3)$ & \\
Low & $12(3.6)$ & $75.4(19.5)$ & \\
Take insulin injections as recommended & & & \\
(n=120) & $113(94.2)$ & $80.1(13.1)$ & \\
Desirable & $3(0.8)$ & $73.0(24.5)$ & \\
Moderate & $4(3.3)$ & $60.0(27.3)$ & \\
Low & & & \\
Take the indicated number of diabetes & & & \\
medication (n=302) & $281(93.0)$ & $81.2(13.6)$ & \\
Desirable & $10(3.3)$ & $74.8(17.3)$ & \\
Moderate & $11(3.6)$ & $76.6(20.05)$ & \\
Low & & & \\
\hline
\end{tabular}

${ }^{*}$ ANOVA test, statistically significant value $p<0.05$.

Table 2 - Smoking habits of the study participants according to the QAD. Florianópolis - SC, Brazil, 2015 to 2016.

\begin{tabular}{lcc}
\hline PAF Domain - Smoking & Frequency & $\mathbf{n ~ ( \% )}$ \\
\hline Have you smoked in the last seven days? & No & $327(90.3)$ \\
When did you last smoke? & Yes & $35(9.7)$ \\
& Never smoked & $206(56.9)$ \\
& More than two years ago & $112(30.9)$ \\
& One to two years ago & $10(2.8)$ \\
& Four to twelve months ago & - \\
& One to three months ago & - \\
& Last month & $4(1.1)$ \\
& Today & $30(8.3)$ \\
\hline
\end{tabular}

\section{DISCUSSION}

The sociodemographic characteristics of the study participants are similar to other studies with people with DM, which also highlight the predominance of females, the elderly, married and retirees or pensioners, with low education levels.,10,18-19 The high prevalence of hypertension was identified in the participants, corroborating with other studies. ${ }^{10,19}$ In the studied sample, only $21 \%$ reported complications related to DM, characterizing a small portion of people in the studied sample, different from what was pointed out in another study. ${ }^{19}$

The uniqueness of the association of the instruments applied in the sample of this study led us to compare our findings with studies that presented descriptive data about self-care due to the lack 
of research that made associations between self-care (specified by items) and resilience in people with $\mathrm{DM}$, as revealed in the present research.

Among the analyzed aspects of self-care, four of them showed statistically significant differences: follow a healthy diet; follow diet guidelines; consumption of sweets; and taking insulin injections as recommended.

Regarding the general diet domain, the two items that make up this domain were statistically significant with the mean resilience. Those participants with desirable self-care, in both items, had high resilience means. Following a healthy diet based on the guidelines recommended by health professionals contributes to the management of the disease and the achievement of ideal care practices, leading to greater autonomy, coping with the disease and self-efficacy, characteristics linked to the resilience construct in relation to the management of chronic disease ${ }^{20}$ Regarding the specific diet domain, only the consumption of sweets was significant with resilience, showing that people with desirable behaviors regarding the consumption of sweets were more resilient.

Proper follow-up of the diet plan is recommended by national ${ }^{21}$ and international guidelines, ${ }^{22}$ based on the choice of food quality, number of meals, control of the intake of foods rich in fats, as well as carbohydrates and milk derivatives. However, this aspect is closely influenced by cultural habits, often not followed properly, as seen in other studies that mention the difficulty that people with DM have in maintaining healthy eating habits. ${ }^{15,23}$ In this context, the study shows that promoting resilience in people with DM can be an important way to improve adherence to the diet, deemed as one of the most difficult aspects in controlling DM. ${ }^{24}$

Regarding blood glucose monitoring, those with desirable self-care actions regarding the use of insulin had a high resilience means: in contrast, despite only being a few individuals, those with low self-care behavior had statistically significant low resilience means. Monitoring capillary blood glucose highlights blood glucose levels and allows autonomy, which in turn brings benefits, since it contributes to decision-making and disease control, ${ }^{25}$ and its performance is recommended three times a day for individuals who use insulin and between two to four weekly tests for those who do not use it. ${ }^{21}$

Although few self-care items have been associated with the resilience of people with DM, we highlight its potential in promoting appropriate health behaviors ${ }^{26}$, pointing out that the construct contributes to the management of chronic disease, from overcoming adversity and stressful situations arising from the condition. ${ }^{8}$

Studies on resilience in people with DM have shown a favorable association between resilience and treatment adherence, i.e., people with higher resilience scores had better treatment adherence ${ }^{11,27}$ and also, better quality of life. ${ }^{28}$

The other domains of self-care were not statistically relevant, nevertheless, it is worth highlighting the findings regarding the frequency of the studied sample's behaviors. Regarding the use of medicines, desirable behaviors were found among most participants, corroborating with other studies that also point out that, in relation to care, the use of medicines tends to have better adherence among people with DM. ${ }^{15,23}$

However, care consists of integrated practices that also involve other commitments for those with DM, such as performing regular physical activities. For this domain, we identified weaknesses in the sample studied, and most participants did not incorporate physical activity in their self-care actions, as recommended by international and national guidelines, which recommend the need for at least 150 minutes of weekly physical activities. ${ }^{21-22}$ Other authors also highlight the difficulty in adhering to physical activity practices in this population. ${ }^{4,19,28}$

Regarding foot care, even though there are no statistical differences, those who follow desirable behaviors had higher resilience means. Regarding this dimension, it is worth mentioning that about 30 to $40 \%$ of the participants have undesirable behaviors related to foot examination and checking the 
inside of the shoes before putting them on, as mentioned by other studies, highlighting the relevance of health education for the modification of these behaviors. ${ }^{19,24}$

With regard to smoking, as found in other studies, the vast majority do not smoke. ${ }^{15,19,23,29}$

In this study, only self-care was associated with resilience. This can be a limitation, due to the fact that resilience is a construct that encompasses the individual in their integral context. Considering this, the investigation was only limited to self-care and did not consider other biopsychosocial aspects inherent to the individual and that can influence resilience. Even so, we consider the relevance of these findings evidenced by the significant statistical differences. The scarcity of studies focusing on the relationship between resilience and self-care in the control of DM was a limitation for understanding the implications of the results obtained in the present study. Therefore, we suggest further studies that contemplate these variables as well as others that may be related to the capacity for self-care for future comparisons.

\section{CONCLUSION}

When investigating the relationship between resilience and self-care of people with DM attended in PHC, it is concluded that four domains showed a statistically significant association when compared to the mean resilience scores, with emphasis on: healthy eating and professional guidance; reduced intake of sweets; recommended frequency of blood glucose assessment. The results obtained point to the potential relationship between high resilience averages and adequate performance in diabetes care.

The promotion of resilience is relevant in the health care of people with DM, as it emerges as a possibility in the clinical practice of nurses, since it contributes to the management of chronic disease by allowing better coping with the disease, ensuring autonomy, confidence and competence to perform the care required and live harmoniously with a chronic health condition. We emphasize the need for studies that explore the association of resilience and self-care in people with DM along with other variables, such as stress, depression, anxiety, as well as the evaluation of strategies to promote resilience.

\section{REFERENCES}

1. International Diabetes Federation (IDF). 8th ed. Diabetes Atlas; 2017 [cited 2017 Mar 10]. Available from: http://www.diabetesatlas.org/resources/2017-atlas.html

2. Ministério da Saúde (BR). Vigilância de Fatores de Risco e Proteção para Doenças Crônicas por Inquérito Telefônico: VIGITEL. Brasília, DF(BR): MS; 2013.

3. Coelho ACM, Boas LCGV, Gomides DS, Foss-Freitas MC, Pace AE. Self-care activities ans their relationship to metabolic and clinical control of people with diabetes mellitus. Texto Contexto Enferm [Internet] . 2015 [cited 2018 Mar 04];24(3):697-705. Available from: http://dx.doi.org/10.1590/010407072015000660014.

4. Boas LCGV, Foss MC, Foss-Freitas MC, Torres HC, Monteiro LZ, Pace AE. Adesão à dieta e ao exercício físico das pessoas com diabetes mellitus. Texto Contexto Enferm [Internet]. 2011[cited 2018 Mar 04];20(2):272-9. Available from: http://dx.doi.org/10.1590/S0104-07072011000200008.

5. Faria HTG, Santos MA, Arrelias CCA, Rodrigues FFL, Gonela JT, Teixeira CRS, et al. Adherence to diabetes mellitus treatments in Family Health Strategy Units. Rev Esc Enferm USP [Internet]. 2014 [cited 2018 Mar 04];48(2):257-63. Available from: http://dx.doi.org/10.1590/S0080623420140000200009

6. Rezende NDS, Silva ARV, Silva GRF. Adherence to foot self-care in diabetes mellitus patients. Rev Bras Enferm [Internet]. 2015 [cited 2018 Mar 04];68(1):111-6. Available from: http://dx.doi. org/10.1590/0034-7167.2015680115p 
7. Rutter M. Resilience as a dynamic concept. Develop Psychopathol [Internet]. 2012 [cited 2018 Mar 06];24(2):335-44. Available from: http://dx.doi.org/10.1017/S0954579412000028

8. Cal SF, Sá LR, Glustak ME, Santiago MB. Resilience in chronic diseases: A systematic review. Cogent Psychology [Internet]. 2015 [cited 2018 Mar 06];2:1024928. Available from: https://dx.doi. org/10.1080/23311908.2015.1024928

9. Nawaz A, Malik JA, Batool A. Relationship between resilience and quality of life in diabetics. J. Coll Physicians Surg Pak [Internet]. 2014 [cited 2018 Mar 09];24(9):670-5. Available from: https:// pubmed.ncbi.nlm.nih.gov/25233974-relationship-between-resilience-and-quality-of-life-in-diabetics/

10. Böell JEW, Silva DMGV, Hegadoren KM. Sociodemographic factors and health conditions associated with the resilience of people with chronic diseases: a cross sectional study. Rev Latino-Am Enferm [Internet]. 2016 [cited 2018 Mar 04];24:e2786. Available from: http://dx.doi. org/10.1590/1518-8345.1205.2786

11. Corathers SD, Kichler JC, Fino NF, Lang W, Lawrence JM, Raymond JK, Dolan LM. High health satisfaction among emerging adults with diabetes: Factors predicting resilience. Health Psychol. 2017 [cited 2018 Feb 28];36(3):206-14. Available from: https://dx.doi.org/10.1037/hea0000419

12. Nassar SM, Wronscki VR, Ohira M, Diniz D. SEstatNet - Sistema Especialista para o Ensino de Estatística na Web. [Internet]. Florianópolis, SC(BR): Universidade Federal de Santa Catarina; 2012 [cited $2015 \mathrm{Jul}$ 08]. Available in: http://www.sestatnet.ufsc.br

13. Connor KM, Davidson JRT. Development of a new Resilience Scale: The Connor-Davidson Resilience Scale (CD-RISC). Depress Anxiety. [Internet]. 2003 [cited 2017 Jan 15];18:76-82. Available from: http://onlinelibrary.wiley.com/doi/10.1002/da.10113/pdf

14. Solano JPC, Bracher ESB, Faisal-Cury A, Ashmawi HA, Carmona MJC, Lotufo NF, et al. Factor structure and psychometric properties of the Connor-Davidson resilience scale among Brazilian adult patients. Sao Paulo Med. J. [Internet]. 2016 [cited 2018 Mar 04];134(5):400-6. Available from: https://dx.doi.org/10.1590/1516-3180.2015.02290512

15. Michels MJ, Coral MHC, Sakae TM, Damas TB, Furlanetto LM. Questionário de Atividades de Autocuidado com o Diabetes: tradução, adaptação e avaliação das propriedades psicométricas. Arq Bras Endocrinol Metab [Internet]. 2010 [cited 2018 Mar 04];54(7):644-51. Available from: https://dx.doi.org/10.1590/S0004-27302010000700009

16. Glasgow RE, Toober DJ, Hampson SE. The summary of diabetes self-care activities measure. Diabetes Care [Internet]. 2000 [cited 2018 Mar 04];23(7):943-50. Available from: https://dx.doi. org/10.2337/diacare.23.7.943

17. IBM Corp. Released 2011. IBM SPSS Statistics for Windows, Version 20.0. Armonk, NY(US): IBM Corp; 2011.

18. Felix L, Bezerra A, Lemos L, Negreiros R, Medeiros F, Souza A, et al. Adherence of older people with diabetes to self-care activities: a study on gender differences. Inter Arc Med [Internet]. 2016 [cited 2017 Dec 03];9(364):1-9. Available from: http://dx.doi.org/10.3823/2235

19. Veras VS, Santos MA dos, Rodrigues FFL, Arrelias CCA, Pedersoli TAM, Zanetti ML. Selfcare among patients enrolled in a self-monitoring blood glucose program. Rev Gaúcha Enferm [Internet]. 2014 [cited 2018 Mar 04];35(4):42-8. Available from: http://dx.doi.org/10.1590/19831447.2014.04.47820

20. Stewart DE, Yuen T. A systematic review of resilience in the physically ill. Psychosomatics [Internet]. 2011 [cited 2018 Mar 04];52(3):199-209. Available from: https://dx.doi.org/10.1016/j. psym.2011.01.036

21. Sociedade Brasileira de Diabetes (SBD). Diretrizes da Sociedade Brasileira de Diabetes 20152016. São Paulo: AC Farmacêutica, [Internet]. 2016 [cited 2018 Mar 04]. Available from: http:// www.diabetes.org.br/profissionais/images/docs/diretrizes-sbd-2015-2016.pdf 
22. American Diabetes Association (ADA). Standards of Medical Care in Diabetes 2015. Diabetes care. [Internet]. 2015 [cited 2017 Nov 21];38(Supp 1):S1-S93. Available from: https://dx.doi. org/10.2337/dc15-S001

23. Ferreira PSG, Peters AS, Morra FL, Pinto KJ, Silva ANA. A adesão ao autocuidado influencia parâmetros bioquímicos e antropométricos de pacientes diabéticos tipo 2 atendidos no programa hiperdia do município de Juiz de Fora, Minas Gerais, Brasil. Nutr Clin Diet Hosp [Internet]. 2014 [cited 2018 Jan 15];34(3):10-9. Available from: https://www.researchgate.net/ publication/273130627_articulo_original

24. Gomides DS, Villas-Boas LCG, Coelho ACM, Pace AE. Self-care of people with diabetes mellitus who have lower limb complications. Acta Paul Enferm [Internet]. 2013 [cited 2018 Mar 04];26(3):289-93. Available from: https://dx.doi.org/10.1590/S0103-21002013000300014

25. Dlugasch LB, Ugarriza DN. Self-monitoring of blood glucose experiences of adults with type 2 diabetes. J Am Assoc Nurse Pract [Internet]. 2013 [cited 2018 Jan 15];26:323-9. Available from: https://dx.doi.org/10.1002/2327-6924.12042

26. Shrivastava A, Desousa A. Resilience: A psychobiological construct for psychiatric disorders. Indian J Psychiatry [Internet]. 2016 [cited 2018 Jan 10];58:38-43. Available from: https://dx.doi. org/10.4103/0019-5545.174365

27. Denisco S. Exploring the relationship between resilience and diabetes outcomes in African Americans. J Am Acad Nurse Pract [Internet]. 2011 [cited 2018 Feb 10];23(11):602-10. Available from: https://dx.doi.org/10.1111/j.1745-7599.2011.00648.x

28. Livingstone W, Mortel TFVD, Taylor B. A path of perpetual resilience: exploring the experience of a diabetes-related amputation through grounded theory. Contemp Nurse. [Internet]. 2011 [cited 2018 Jan 15];39(1):20-30. Available from: https://dx.doi.org/10.5172/conu.2011.39.1.20

29. Zhou Y, Liao L, Sun M, HE G. Self-care practices of Chinese individuals with diabetes. Exp and Ther Med. Internet]. 2013 [cited 2018 Feb 10];5(4):1137-42. Available from: https://dx.doi. org/10.3892/etm.2013.945 


\section{NOTES}

\section{ORIGIN OF THE ARTICLE}

Extracted from the thesis - Factors associated with the resilience of people with diabetes mellitus, presented to the Graduate Program in Nursing at the Universidade Federal de Santa Catarina, in 2017.

\section{CONTRIBUTION OF AUTHORITY}

Study design: Boell JEW, Silva DMGV, Hegadoren K.

Data collection: Boell JEW, Suplici SR.

Analysis and interpretation of data: Boell JEW, Silva DMGV, Hegadoren K, Guanilo MEE, Meirelles BHS, Suplici SR.

Discussion of results: Boell JEW, Silva DMGV, Hegadoren K, Guanilo MEE, Meirelles BHS, Suplici SR. Critical writing and/or content review: Boell JEW, Silva DMGV, Hegadoren K, Guanilo MEE, Meirelles BHS, Suplici SR.

Final revision and approval of the final version: Boell JEW, Silva DMGV, Hegadoren K.

\section{ACKNOWLEDGMENTS}

We thank Coordenação de Aperfeiçoamento de Pessoal de Nível Superior (CAPES ) for the postdoctoral fellowship provided to Julia Estela Willrich Boell. And Conselho Nacional de Desenvolvimento Científico e Tecnológico (CNPq) for provided the productivity grant to Denise Maria Guerreiro Vieira da Silva.

\section{FUNDING INFORMATION}

National Council for Scientific and Technological Development (CNPq)

\section{APPROVAL OF ETHICS COMMITTEE IN RESEARCH}

Approved by the Research Ethics Committee of the Universidade Federal de Santa Catarina, opinions no.580,587 and No.1,960,220, CAAE: 21888614.4.0000.0121.

\section{CONFLICT OF INTEREST}

There is no conflict of interest.

\section{HISTORY}

Received: March 26, 2018.

Approved: June 28, 2018.

\section{CORRESPONDING AUTHOR}

Julia Estela Willrich Boell

juliasuporte@gmail.com 